\title{
Poecilimon zonatus Bolívar (ORTHOPTERA, TETTIGONIIDAE) REVISITED: GENETIC DATA REVEALED TWO NEW SPECIES AND ONE NEW SUBSPECIES
}

\author{
Sarp KAYA \\ Vocational School of Health Services, Mehmet Akif Ersoy University, Burdur, TURKEY \\ Corresponding author: e-mail: sarpkaya@mehmetakif.edu.tr
}

Cite this article as:

Kaya S. 2018. Poecilimon zonatus Bolívar (Orthoptera, Tettigoniidae) Revisited: Genetic Data Revealed Two New Species and One New Subspecies. Trakya Univ J Nat Sci, 19(1), 85-99, DOI: 10.23902/trkjnat.411785

Received: 02 April 2018, Accepted: 10 April 2018, Online First: 12 April 2018, Published: 15 April 2018

\begin{abstract}
Poecilimon Fischer (Orthoptera, Tettigoniidae) is the most species-rich genus of the respective order and family in Anatolia. However, intrageneric diversity still needs to be documented. Poecilimon zonatus Bolívar is a species with a relatively wide range of distribution in Anatolia compared to other congeners. The present study aims to examine the diversity of $P$. zonatus using an integrated approach. The diversity of the species was documented using data based on DNA sequences, male calling song and morphology. Automatic species delimitation tests applied to genetic data revealed a cryptic diversity in $P$. zonatus complex and suggested two new species and one new subspecies. The song data supported the new species, but morphology remained less productive in this respect. The new taxa defined in the light of the obtained data are; Poecilimon isozonatus sp. n., Poecilimon ciplaki sp. n. as Poecilimon ciplaki ciplaki subsp. n. and Poecilimon ciplaki denizliensis subsp. n. These taxa together with $P$. zonatus were considered a species complex within $P$. zonatus group. The phylogenetic tree produced from $n a d 2$ gene sequences supported the following relationships of $P$. tauricola $+(P$. ciplaki $+(P$. zonatus $+P$. isozonatus)) relationship.
\end{abstract}

Key words: Anatolia, Poecilimon isozonatus sp. n., Poecilimon ciplaki sp. n., Poecilimon ciplaki ciplaki subsp. n., Poecilimon ciplaki denizliensis subsp. n., phylogeny.

Özet: Poecilimon Fischer (Orthoptera, Tettigoniidae), dahil olduğu takım ve familyanın Anadolu'da tür sayısı en fazla olan cinstir. Ancak cins içi çeşitlilik halen ortaya konmayı beklemektedir. Cinsin diğer türleri ile karşılaştırıldığında Poecilimon zonatus Bolívar Anadolu'da nispeten geniş yayılışa sahip bir türdür. Bu çalışma entegre bir yaklaşımla türün çeşitliliğini saptamayı amaçlamaktadır. DNA dizileri, erkek çağrı sesi ve morfolojiden üretilen verilerle $P$. zonatus türünün çeşitliliği tanımlanmıştır. Genetik verilere uygulanan otomatik tür sınırları testleri $P$. zonatus'un kriptik bir çeşitlilik içerdiğini ve iki yeni tür ile bir yeni alttürün varlığına işaret etmiştir. Erkek çağrı sesi verileri yeni türleri desteklemiştir. Ancak, bu açıdan morfoloji daha az kullanışlı olmuştur. Elde edilen bu veriler ışığında tanımlanan yeni taksonlar şunlardır; Poecilimon isozonatus sp. $\mathrm{n}$. Poecilimon ciplaki sp. n. ve Poecilimon ciplaki ciplaki subsp. n. ve Poecilimon ciplaki denizliensis subsp. n. Bu yeni taksonlar $P$. zonatus ile birlikte $P$. zonatus kompleksi olarak tanımlanmış ve bu kompleksin $P$. zonatus tür grubu içinde yer aldığ sonucuna varılmıştır. nad 2 gen dizilerinden üretilen filogenetik ağaç $P$. tauricola $+(P$. ciplaki $+(P$. zonatus $+P$. isozonatus $))$ akrabalık ilișkisini desteklemiştir.

\section{Introduction}

Poecilimon Fischer is one of the largest genera of Phaneropterinae by its species number running into 130 (Cigliano et al. 2018). Most of these species were arranged into 19 species groups, but 18 species still have not been assigned to any of the known groups (Cigliano et al. 2018). Ramme (1933), the first who arranged Poecilimon in groups, listed eight species in Group III and proposed $P$. zonatus Bolivar, 1899 and $P$. varicornis (Haan, 1843) to be closely related among others. Another related species is $P$. variicercis Miram. Ramme (1951) in the original description of $P$. tauricola compared it with $P$. zonatus and $P$. varicornis, but he did not mention $P$. variicercis. Cigliano et al. (2018) reported that
Poecilimon zonatus species group included $P$. zonatus, $P$. variicercis, and $P$. tauricola, but not $P$. varicornis. Ullrich et al. (2010) presented a phylogeny of Barbitistini based on two genetic markers and both of the trees supported monophyly of the group, but $P$. variicercis was not among the species studied. Among the taxa listed above, $P$. zonatus has by far the widest range, but animals from different parts within the range of the species exhibit differences supporting the idea that a complex of taxa are included under this name (Çıplak et al. 1996, Ünal 2010, Sevgili et al. 2012) and thus, need to be examined more in detail. 
Although the species number of the genus Poecilimon is high, its range size is comparatively narrow. Vast majority of the species are known from Anatolia and Greece/Balkans and only a few species occur outside this core area (La Greca 1999). Based Çıplak (2004) suggested, considering such distributional pattern of members of the genus, that the genus originated from an ancestral stock within the historical Aegeid Plate. Diversity in ecological preferences of generic members seems to be another factor promoting intra-generic diversity (Kaya et al. 2015). Some intra generic lineages are confined to lowlands while some others to mountain chains. Anatolia harbours a pronounced diversity of the genus (Çıplak 2008). Poecilimon zonatus is a species endemic to Anatolia and its distribution is mostly associated with highlands. The distribution pattern indicates that both tectonic evolution of the area and the ecological diversity provided by highlands may have played as evolutionary drivers leading to radiation of the P. zonatus species complex (Çıplak 2004, 2008, Kaya et al. 2015). Inferring from this pattern, we concluded that further localities in Anatolia should be studied, which in turn allowed us to detect an extra diversity of the species group, especially throughout Taurus Mountain range along Mediterranean Anatolia.

The results of the studies on the species group was presented and new taxa belonging to $P$. zonatus group were described by providing necessary illustrations, presenting male calling songs for a better description of the new taxa and diagnosing them. The study, on the other hand, does not aim a detailed phylogeny or phylogeography of the species group. During our ongoing studies, DNA sequence data were obtained indicating a cryptic diversity in $P$. zonatus s. str. ( $P$. zonatus complex here after). Thus, a sufficient number of sequences per population was analysed by applying basic phylogenetic analyses and automatic species delimitation tests applied to detect independent evolutionary or reproductive units.

\section{Materials and Methods}

Sampling, molecular studies, phylogenetic analyses and automatic species delimitation tests

Samples of $P$. zonatus group were collected from different location throughout Anatolia during 1992-2015. Twenty different populations were sampled and of these the Muğla-Fethiye population is from lowland (285m) while remaining 19 are from Anatolian higlands. Samples collected prior to 2000 were prepared as dry material while those after this date were preserved in $96 \%$ ethanol for molecular studies.

Studies on members of Phaneropterinae showed that mitochondrial NADH dehydrogenase 2 (nad2) gene is highly variable and contains a significant amount of phylogenetic information (Chobanov et al. 2017). We obtained and used a few sequences per population to test distinctness of the taxa in the group. For amplification of the nad2 region the forward primer TM-J210 and reverse primers TW-N1284 or TY-N1433 (Simon et al. 2006) were used. The protocols given in Chobanov et al. (2017) were followed for DNA isolation and PCR.

The sequences were aligned manually in Sequencher v. 4.1 (Gene Codes Corporation, Ann Arbor, MI, USA) and checked manually by eye. Each sequence of nad 2 was checked using DnaSP v.5 (Librado \& Rozas 2009) to detect NUMTs (nuclear mitochondrial genes) and to determine unique haplotypes. Nucleotide sequences of each unique haplotype identified in this study are deposited in the Genbank database (see Table 1). The parameters and best fit evolutionary model for data matrix were estimated by jModelTest v.0.1.1 (Darriba et al. 2012). The matrix was analysed with maximum likelihood (ML) and ML-bootstrap using RaXML v.1.3.1 (Silvestro \& Michalak 2012) with ML-rapid 1000 bootstrap option. The selected model was implemented in ML analysis. One sequence per Poecilimon cervus Karabag (GenBank acc: MH168578) and P. inflatus Brunner von Wattenwyl (GenBank acc: MH168579) were chosen as outgroups. Four different DNA sequence-based species delimitation tests were applied to detect independently evolved lineages in the dataset and to make a taxonomic decision more objectively: (i) statistical parsimony (SP), (ii) distance-based test SpeciesID (SpeID), (iii) the Automatic Barcode Gap Discovery (ABGD), and (iv) the Bayesian implementation of the Bayesian Poisson Tree Process model (bPTP). See Kaya $\&$ Çıplak (2017) for the application procedures and the software used.

\section{Morphology and bioacoustics}

Specimens collected during field studies were prepared as museum material by standard methods or preserved in $96 \%$ alcohol. The material examined in this study is preserved in Akdeniz University, Department of Biology, Zoological Museum, Antalya, Turkey (AUZM). We also benefitted from the images of type specimens given in Orthoptera Species File2 (Cigliano et al. 2018) and SysTax-DORSA. Morphological structures of the investigated specimens were photographed, qualitatively examined and measured using a digital camera attached to a Leica MZ6/DC200 stereomicroscope and Image J v.1.36 (http://rsb.info.nih.gov/ij/). We paid particular attention for qualitative examinations of the cerci in males, the pronotum, tegmina and subgenital plate in males and females, and ovipositor in females since former descriptions and diagnoses of Poecilimon species were based mainly on these characters (Ramme 1933, BeyBienko 1954, Harz 1969, Ünal 2010, Kaya et al. 2012).

For sound recordings, a FOSTEX FR-2 (frequency response 22.05-192kHZ, all records have been made in the range of $46-98 \mathrm{kHz}$ frequency responses) digital recorder was used with a G.R.A.S. Type 40BF microphone (frequency response $10 \mathrm{~Hz}-40 \mathrm{kHz} \pm 1.0 \mathrm{~dB}$, $4 \mathrm{~Hz}-100 \mathrm{kHz} \pm 1.0 \mathrm{~dB}$ ). Oscillograms and sound analyses were made using Turbolab (Stemmer AG) and CoolEdit Pro. V. 2.0 (Syntrillium Software Corporation). The figures of waveform (oscillogram) and power of frequency spectra (spectrogram) were produced using 


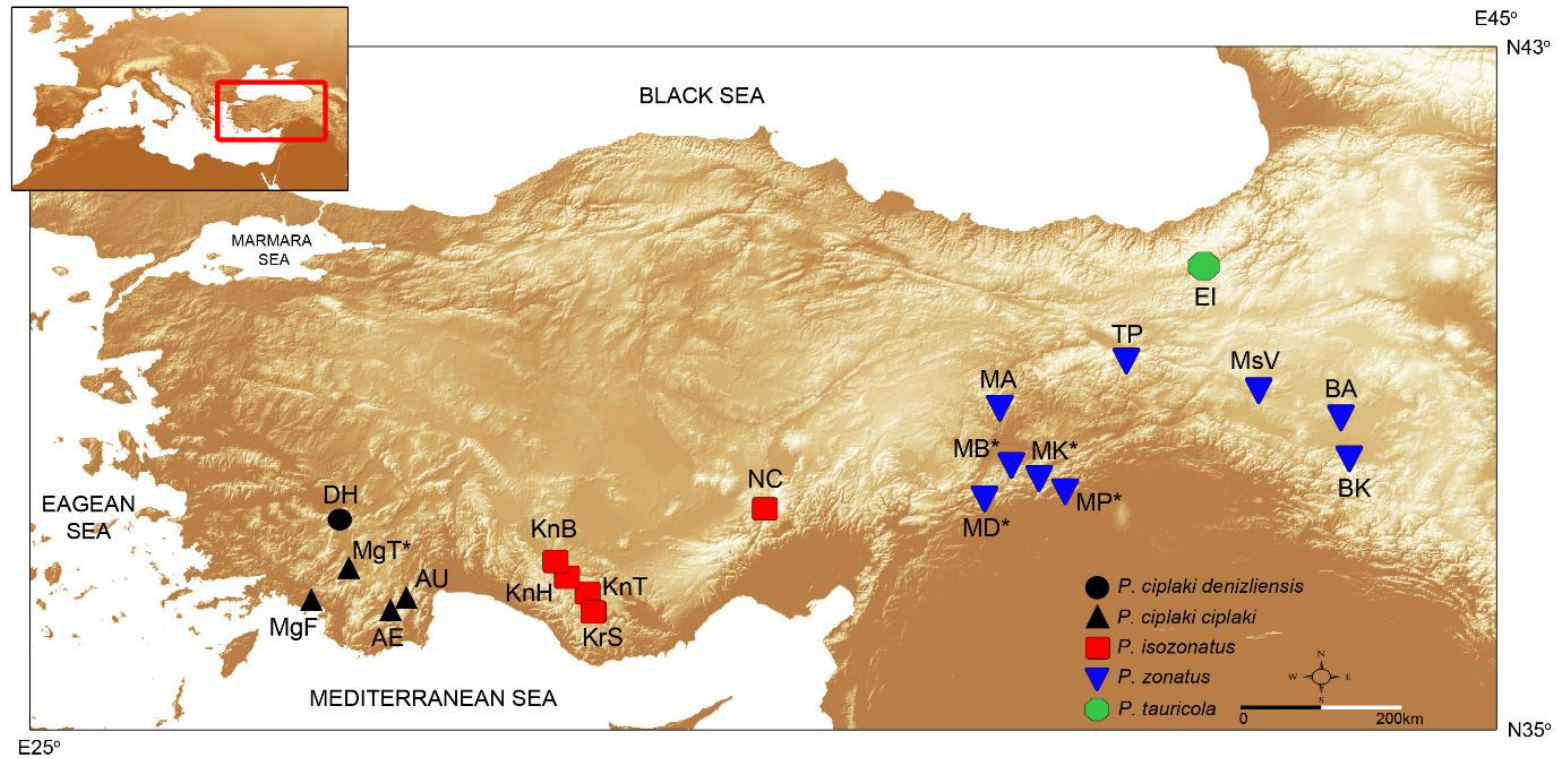

Fig. 1. Distribution map of sampling localities of P. zonatus complex and P. tauricola. (AE: Antalya-Elmal1, AU: Antalya Uzunkarış Mt., BA: Bitlis-Adilcevaz, BK: Bitlis-Kuskunkıran pass, DH: Denizli-Honaz, MgF: Muğla-Fethiye, MgT: Muğla-Tuzla pass, KnB: Konya-Bozkır, KnH: Konya-Hadim, KnT:Konya-Taşkent, KrS: Karaman-Sarıveliler, MA: Malatya-Arguvan, MB: Malatya-Beydağı Mt., MD: Malatya-Doğanşehir, MK: Malatya-Kubbe Mt., MP: Malatya-Pütürge, MsV: Muş-Varto, NC: Niğde-Çamardı, EI: Erzurumİspir) * samples not used for molecular studies.

Seewave package version 2.1.0 (Sueur et al. 2008) for the R v. 3.3.4 (R Development Core Team 2018) with the following settings: proper $(46-98 \mathrm{kHz})$ sample ratio, 16-bit amplitude resolution, mono channel, 128 points FFT length, Hanning window function with $80 \%$ overlap.

In song descriptions, the terminology given in Heller (1988) and Kaya et al. (2012) was used as considering Calling song- song produced by an isolated male, syllablethe song produced by one opening-closing movement cycle of the tegmina, impulse- a simple, undivided transient train of sound waves, and $m s-$ millisecond/s.

\section{Results}

Taxonomy on the basis of phylogeny

After alignment and trimming of the sequences, the final sequence length in the nad2 matrix was $992 \mathrm{bp}$ along which 597 sites were constant, 395 were variable, and 239 were parsimony informative. We identified $16+2$ unique haplotypes of ingroup + outgroup from a total of 58 sequences (Table 1). The jModeltest calculated $\operatorname{TrN}+\mathrm{I}+\Gamma$ model with gamma correction $(\Gamma)$ of 0.8380 and the frequency of invariable sites (I) of 0.39 for data sets including outgroups.

ML analysis produced a tree with significantly high bootstrap values for all nodes (Fig. 2). Next to the outgroups on the tree, $P$. tauricola branches off basally and the other haplotypes constitute a monophyletic group. There are three phylogroups in the crown monophyletic group ( $P$. zonatus complex) subsequent to $P$. tauricola, . The haplotypes from westernmost populations (Antalya, Denizli, and Muğla) constitute a sister haplogroup to the remaining haplotypes. The last phylogroup consists of two compact phylogroups, one including haplotypes from the populations sampled from the eastern Mediterranean Part of Anatolia (Konya and Niğde) and the other including the population from the highlands of East Anatolia (Bitlis, Erzincan, Malatya, and Muş).

The automatic species delimitation tests suggested consistent results. The following geographically outlined populations were suggested as distinct species/taxa (Fig. 2); (i) the Erzurum population, (ii) the populations from East Anatolia (Bitlis, Erzincan, Malatya, and Muş) (iii) the populations from the eastern part of Mediterranean Anatolia (Konya and Niğde), and (iv) the populations from the westernmost Mediterranean part of Anatolia (Antalya, Denizli, and Muğla) (see Fig. 1). The first population corresponds to Poecilimon tauricola and the second to P. zonatus s. str. as the type locality Binboğa Mts. in association with mountain chains of East Anatolia (see Çıplak 2008). The third and fourth populations represent the new species named below as Poecilimon isozonatus sp. n. and Poecilimon ciplaki sp. n. Denizli population is suggested as a different species by the statistical parsimony, the species ID and Bayesian poison tree process (bPTP) except for automatic barcode gap discovery (it was included in a species together with Antalya and Muğla populations) (Fig. 2). Considering the fact that there are also phenotypic differences distinguishing this population, we considered $P$. ciplaki sp. n. as polytypic with two subspecies: $P$. ciplaki ciplaki subsp. n. and $P$. ciplaki denizliensis subsp. $\mathrm{n}$. 
Table 1. The unique haplotypes of $n a d 2$ gene for each population of $P$. zonatus complex and $P$. tauricola (there are no populations sharing haplotypes among taxa) Numbers next to the locality names correspond to the number of haplotypes of nad 2 in each locality.

\begin{tabular}{|c|c|c|c|c|c|c|c|c|c|c|c|c|c|}
\hline \multirow[t]{2}{*}{$\begin{array}{c}\text { GenBank } \\
\text { Acc. no }\end{array}$} & $\begin{array}{c}\text { Species/ } \\
\text { Subspecies }\end{array}$ & 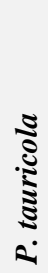 & \multicolumn{4}{|c|}{ 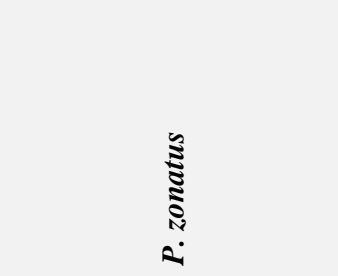 } & & 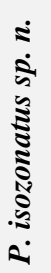 & & \multicolumn{2}{|c|}{ 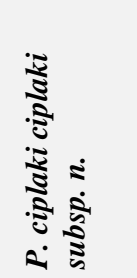 } & 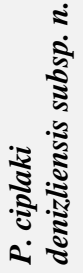 & \multirow[t]{2}{*}{ Total } \\
\hline & $\begin{array}{c}\text { Haplotype/ } \\
\text { Locality }\end{array}$ & $\underset{⿱ 乛 ⿻ コ 一 心 ~}{\Xi}$ & 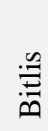 & 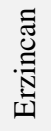 & $\stackrel{\infty}{\Sigma}$ & $\frac{\underset{\pi}{\vec{J}}}{\sum_{\Sigma}^{\pi}}$ & $\begin{array}{l}\stackrel{8}{\stackrel{0}{00}} \\
\stackrel{2}{Z}\end{array}$ & 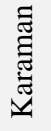 & 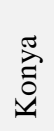 & 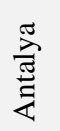 & $\stackrel{\frac{\pi}{100}}{\stackrel{100}{\mid}}$ & 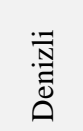 & \\
\hline МH168590 & "Erzurum-1 & 2 & & & & & & & & & & & 2 \\
\hline MH168582 & Bitlis-1 & & 6 & & & & & & & & & & 6 \\
\hline MH168595 & Erzincan-1 & & & 3 & & & & & & & & & 3 \\
\hline MH168589 & Muş-1 & & & & 1 & & & & & & & & 1 \\
\hline MH168586 & Malatya-1 & & & & & 3 & & & & & & & 3 \\
\hline МH168587 & Malatya-2 & & 2 & & & 1 & & & & & & & 3 \\
\hline МH168588 & Malatya-3 & & & & & 1 & & & & & & & 1 \\
\hline МH168583 & Niğde-1 & & & & & & 11 & & & & & & 11 \\
\hline МH168593 & Niğde-2 & & & & & & 2 & & & & & & 2 \\
\hline MH168594 & Karaman-1 & & & & & & & 1 & & & & & 1 \\
\hline MH168584 & Konya-1 & & & & & & & & 2 & & & & 2 \\
\hline MH168585 & Konya-2 & & & & & & & 4 & 8 & & & & 12 \\
\hline МH168591 & Antalya-1 & & & & & & & & & 3 & & & 3 \\
\hline МН168580 & Muğla-1 & & & & & & & & & & 1 & & 1 \\
\hline МH168581 & Muğla-2 & & & & & & & & & & 1 & & 1 \\
\hline MH168592 & Denizli-1 & & & & & & & & & & & 4 & 4 \\
\hline \multicolumn{2}{|c|}{ Total } & 2 & 8 & 3 & 1 & 5 & 13 & 5 & 10 & 3 & 2 & 4 & 56 \\
\hline
\end{tabular}

Table 2. Some song parameters for the species in P. zonatus complex. Mean values of each parameter were given with minimummaximum values in parenthesis ( $\mathrm{N}$ : number of measured syllables).

\begin{tabular}{lcccc}
\hline \hline \multicolumn{1}{c}{ Species (population recorded) } & $\mathbf{N}$ & $\begin{array}{c}\text { Syllable } \\
\text { duration }\end{array}$ & $\begin{array}{c}\text { Impulse number per } \\
\text { syllable }\end{array}$ & $\begin{array}{c}\text { Recording Temperature } \\
\left({ }^{\circ} \mathbf{C}\right)\end{array}$ \\
\hline \hline P. zonatus (Bitlis) & 49 & $\begin{array}{c}8.90 \\
(7-11)\end{array}$ & $11.35(7-16)$ & $25.8,25.9,26.0$ \\
P. isozonatus sp. n. (Konya-Taşkent) & 52 & $\begin{array}{c}18.36 \\
(14-25)\end{array}$ & $28.02(16-36)$ & 25.2 \\
P. ciplaki sp. n. (Muğla-Fethiye) & 20 & $\begin{array}{c}49.00 \\
(42-72)\end{array}$ & $19.30(16-24)$ & 23.5 \\
\hline \hline
\end{tabular}

The pattern of male calling songs is similar in all examined populations. The song consisted of single isolated syllables repeated in irregular periods (see Figs. 3, 4). The main differences between the species were observed in syllable duration and impulse number per syllable (Table 2 ). The species ordered by syllable duration from highest to the lowest are as follows: $P$. ciplaki sp. n. - 49.0ms (42-72ms), P. isozonatus sp. n. - $18.4 \mathrm{~ms}(14-25 \mathrm{~ms}$ ), and (iii) P. zonatus - 8.9ms (7$11 \mathrm{~ms})$. P. isozonatus sp. n. was represented with 28.03 (16-36), P. ciplaki sp. n. with 19.30 (16-24) and $P$. zonatus with 11.35 (7-16) impulses per syllable. It is clear from these results that there are clear gaps between the species in both song parameters allowing us to diagnose them from each other.

\section{Species and subspecies diagnoses}

The data presented here mainly concern $P$. zonatus. We also added a sample population of $P$. tauricola, which is suggested to be a member of the $P$. zonatus group. $P$. zonatus can be easily distinguished from other members of the group by its greenish coloration (black is dominant in others), species specific shape of male cerci and the higher number of stridulatory teeth (64-73 in P. tauricola while less than 56 in others). It is also genetically very distant to the remaining three taxa (Table 3 ).

$P$. zonatus and $P$. isozonatus sp. n. are very similar and cannot be distinguished from each other by the traditionally used structures such as pronotum, cerci, tegmina, and ovipositor, except minor differences exhibited in more slender and apically more tapered male cerci. 


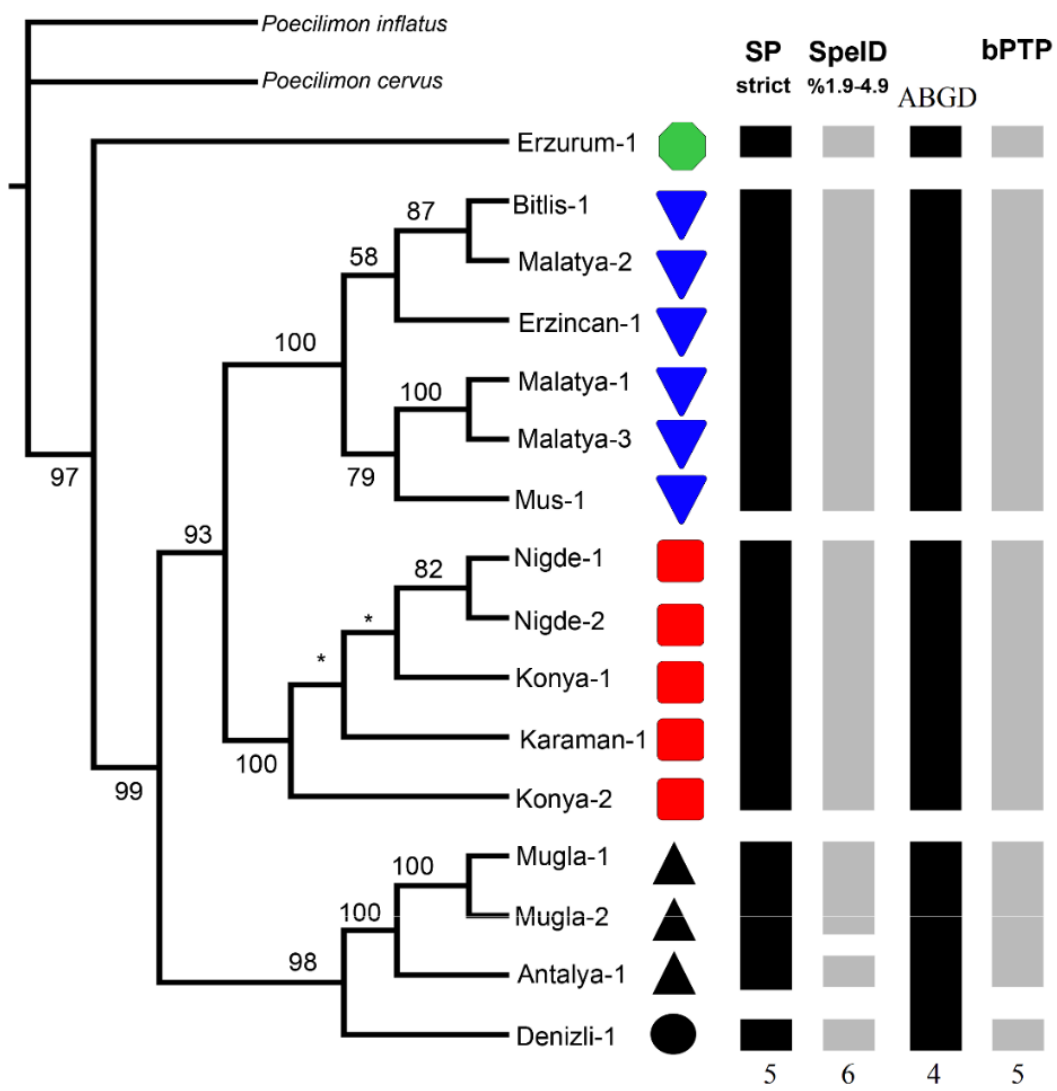

Fig. 2. Phylogenetic tree produced from nad2 matrix and results of automatic species delimitation tests mapped on the tree (SPstatistical parsimony, SpeID- SpeciesID, the ABGD- Automatic Barcode Gap Discovery, bPTP Bayesian implementation of the Poisson Tree Process model).

Table 3. Some measurements for the species in P. zonatus complex and P. tauricola (lengths of pronotum (Pr), hind femur (Hf), ovipositor $(\mathrm{Ov})$, number for cercal denticles $(\mathrm{Cd})$, and stridulatory teeth $(\mathrm{Sp}))$. All measurement values were given in mm and presented as means and their maximum-minimum. NA: not applicable.

\begin{tabular}{|c|c|c|c|c|c|c|}
\hline Species & $\begin{array}{c}\text { Gender } \\
\text { (N) }\end{array}$ & Pr & Hf & Cd & Sp & Ov \\
\hline \multirow{2}{*}{ P. zonatus } & $\hat{\delta}(8)$ & $\begin{array}{c}5.54 \\
5.68-5.42\end{array}$ & $\begin{array}{c}17.03 \\
17.90-16.20\end{array}$ & $\begin{array}{l}9.67 \\
13-8\end{array}$ & $\begin{array}{l}48.70 \\
53-43\end{array}$ & NA \\
\hline & 우 (6-8) & $\begin{array}{c}6.07 \\
6.59-5.57\end{array}$ & $\begin{array}{c}18.41 \\
19.50-17.32\end{array}$ & NA & NA & $\begin{array}{c}12.25 \\
12.88-11.67\end{array}$ \\
\hline \multirow{2}{*}{ P. isozonatus sp. n. } & $\widehat{\partial}(10-15)$ & $\begin{array}{c}5.16 \\
5.82-4.83\end{array}$ & $\begin{array}{c}16.85 \\
17.72-15.50\end{array}$ & $\begin{array}{c}10.00 \\
14-7\end{array}$ & $\begin{array}{l}48.60 \\
56-45\end{array}$ & NA \\
\hline & 우 (11) & $\begin{array}{c}5.09 \\
6.42-3.06\end{array}$ & $\begin{array}{c}18.27 \\
19.15-17.05\end{array}$ & NA & NA & $\begin{array}{c}11.50 \\
12.70-9.24\end{array}$ \\
\hline \multirow[b]{2}{*}{ P. ciplaki sp. n. } & $\delta(3-4)$ & $\begin{array}{c}5.69 \\
6.10-5.38\end{array}$ & $\begin{array}{c}16.82 \\
17.65-16.00\end{array}$ & $\begin{array}{c}7.66 \\
8-5\end{array}$ & $\begin{array}{l}53.33 \\
48-57\end{array}$ & NA \\
\hline & $\hat{\sigma}(7-10)$ & $\begin{array}{c}6.08 \\
6.10-6.07\end{array}$ & $\begin{array}{c}17.66 \\
18.82-16.50\end{array}$ & NA & NA & $\begin{array}{c}11.58 \\
12.17-10.99\end{array}$ \\
\hline \multirow[b]{2}{*}{ P. tauricola } & $\widehat{\delta}(4-5)$ & $\begin{array}{c}5.95 \\
6.35-5.46\end{array}$ & $\begin{array}{c}16.66 \\
17.30-16.00\end{array}$ & $\begin{array}{c}8.00 \\
9-7\end{array}$ & $\begin{array}{l}67.25 \\
73-64\end{array}$ & NA \\
\hline & ๆ (4) & $\begin{array}{c}6.65 \\
7.06-6.22\end{array}$ & $\begin{array}{c}18.03 \\
18.80-17.30\end{array}$ & NA & NA & $\begin{array}{c}9.50 \\
9.72-9.37\end{array}$ \\
\hline
\end{tabular}



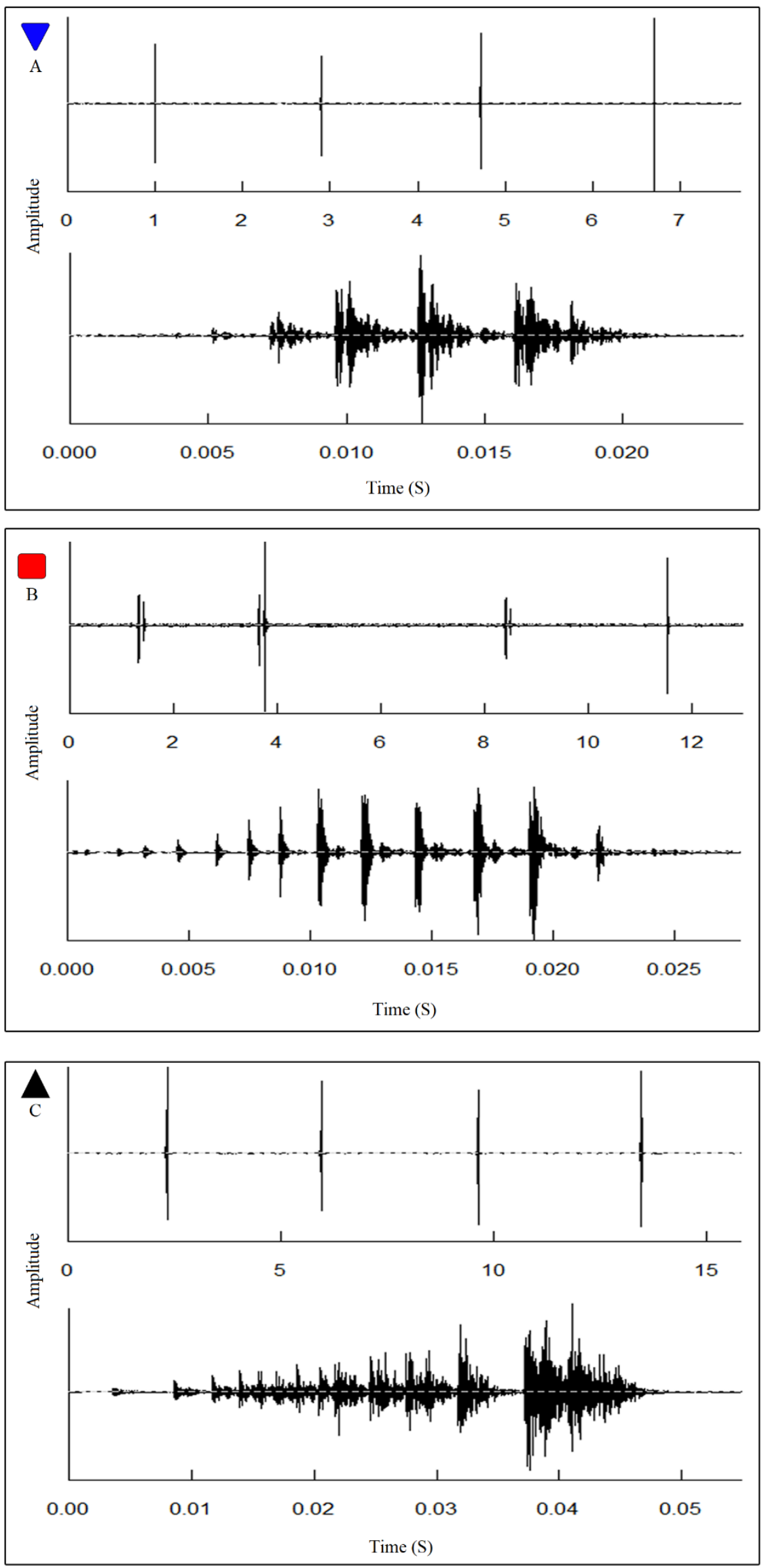

Fig. 3. Oscillograms of male calling songs (syllables): A- P. zonatus, B- P. isozonatus sp. n., C- P. ciplaki ciplaki subsp. n. 


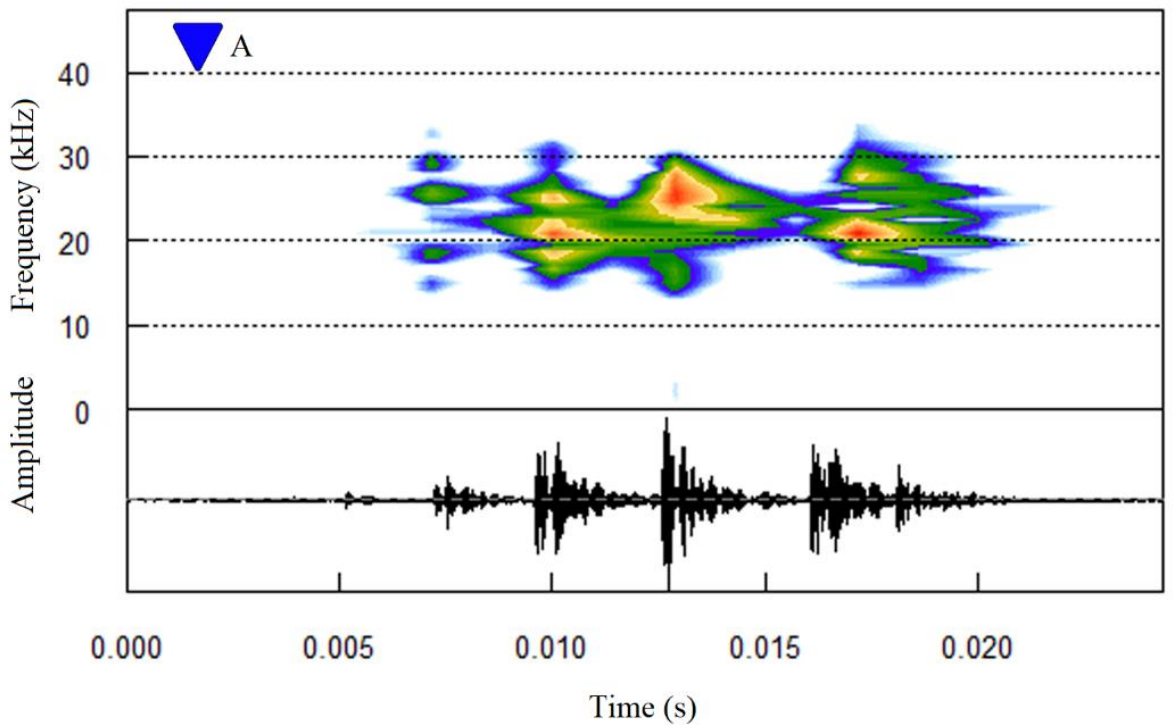

Amplitude (dB)
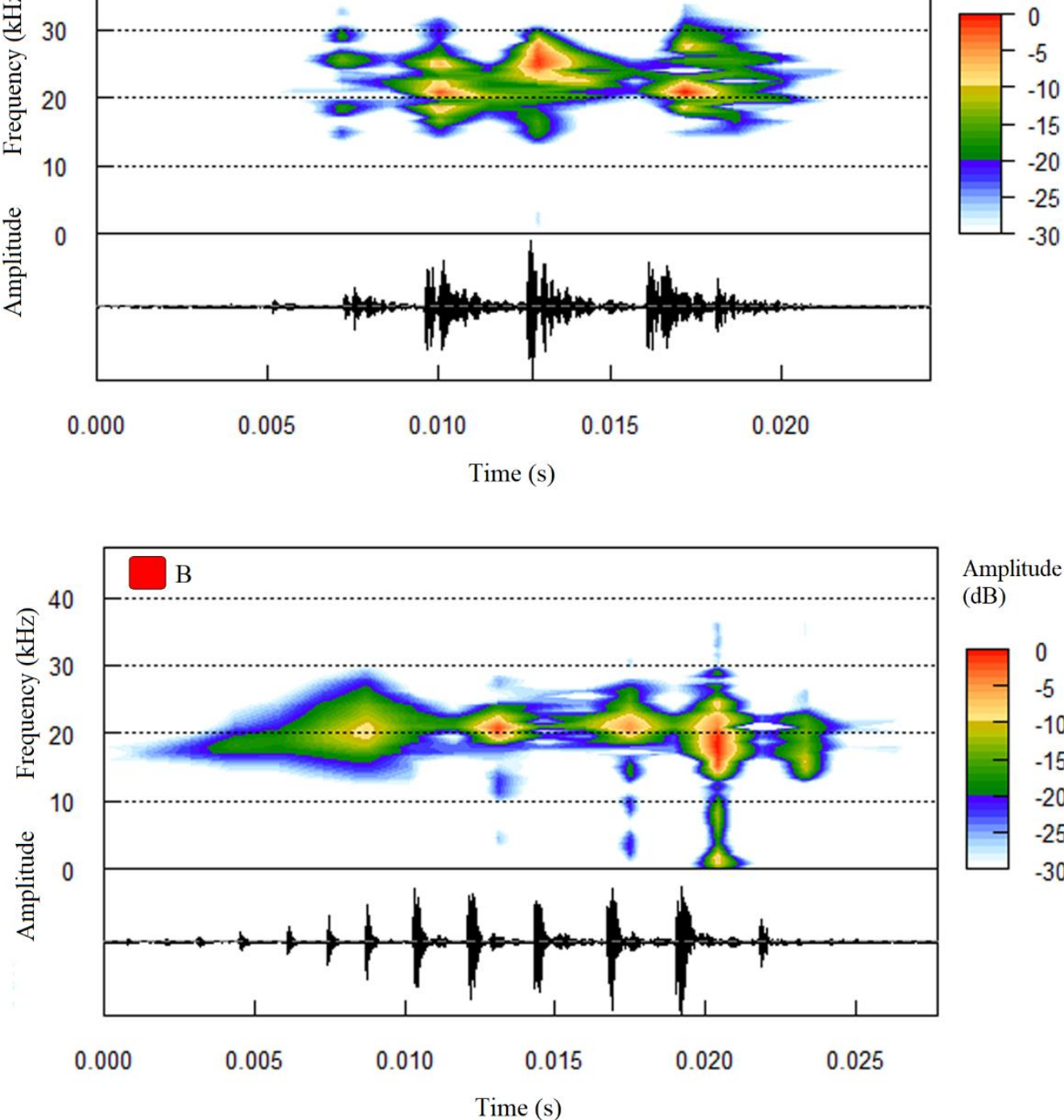

Amplitude

$(\mathrm{dB})$
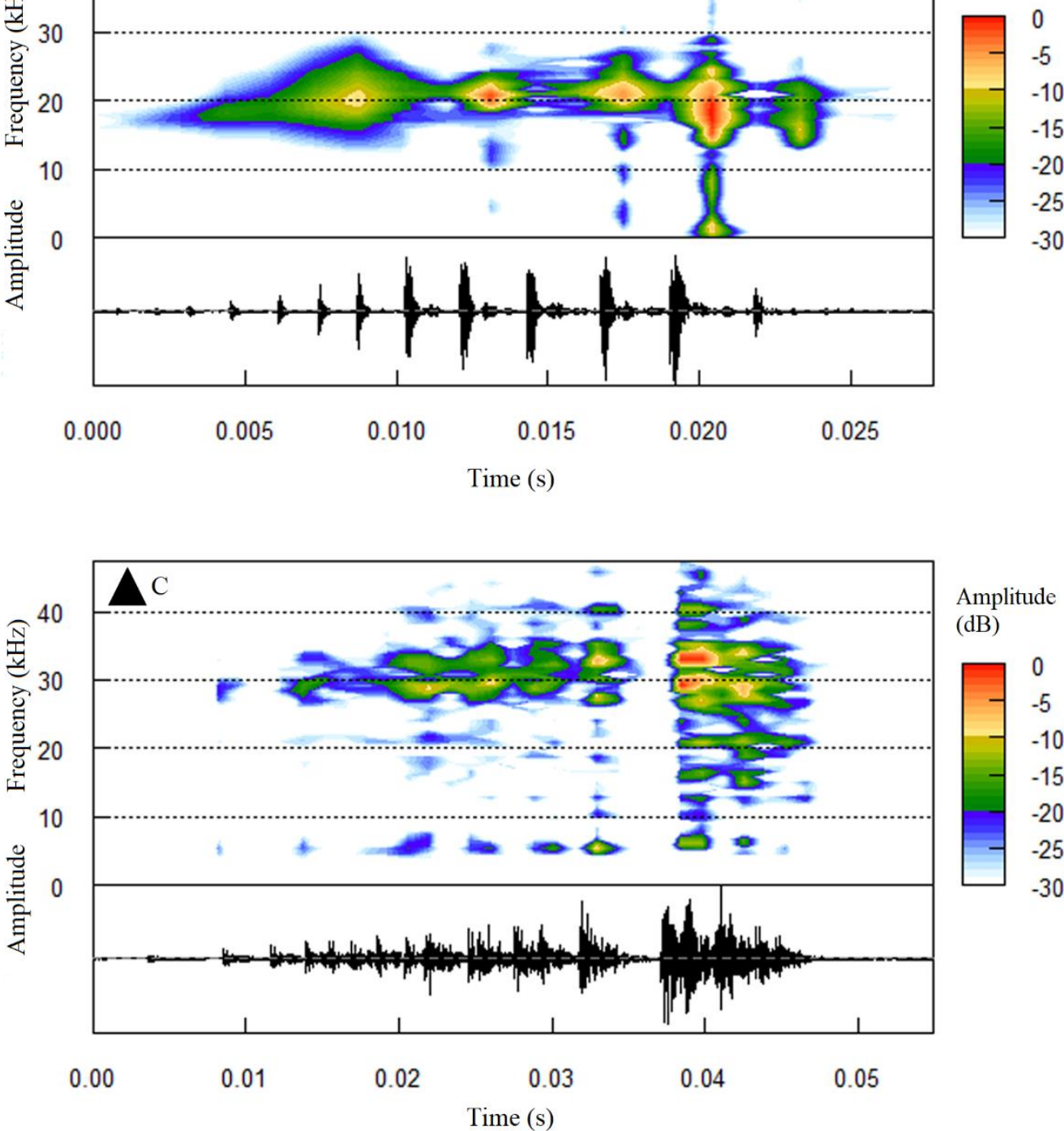

Amplitude

(dB)

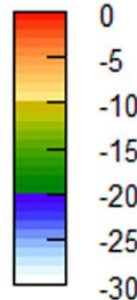

Fig. 4. Power spectra of male calling songs: A- P. zonatus, B- P. isozonatus sp. n., C- P. ciplaki ciplaki subsp. n. 
However, genetic data supported a clear distinction as eachshowed unique haplotypes. The diagnostic characters distinguishing the two taxa are based on male calling songs. The syllable duration is $8.9 \mathrm{~ms}(7-11 \mathrm{~ms})$ and impulse number per syllable is 11.35 (7-16) in $P$. zonatus, while they are 18.6 (14-25) and 28 (16-36), respectively, in P. isozonatus sp. n. (Table 2, Figs. 3, 4).

Poecilimon zonatus Bolívar, 1899

Poecilimon zonatus Bolívar, 1899: 597

Type information. Lectotype male; Marach (Kahramanmaraş), Bimbogha-Dagh (Binboğa Mt.) in Museo Nacional de Ciencias Naturales, Madrid.

Material examined. $2 \lesssim \widehat{\jmath}, 3 q \uparrow$, TURKEY: Van, road to Bitlis-Kuskunkıran Pass, N: 38.37700, E: 42.78647, 2234m, 18.VII.2011, leg. S. Kaya, Z. Boztepe, Ö. Pekter; $8 \widehat{\jmath}, 9$ 웅, Bitlis-Adilcevaz-Harmantepe Vill., $\quad \mathrm{N}$ : 38.86667, E: 42.73333, 2215m, 4.VII.2015, leg. S. Kaya and B. Çıplak; 1\%, Muş-Varto, road to Hınıs, N: 39.19940, E: 41.55625, 2000m, 6.VIII.2012, leg. S. Kaya, Z. Boztepe, Ö. Pekter; $1 \widehat{\jmath}, 2$ 우, Road between ErzincanTunceli,-Pülümür, N: 36.65000, E: 32.63333, 1697m, 8.VII.2009, leg. M. Korkmaz; 5ภ̂̉, 5우, MalatyaArguvan-Çobandere-Eşkınlı, N: 38.98532, E: 38.18311,

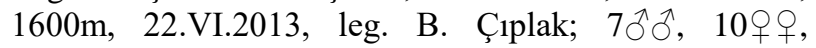
Malatya-Doğanşehir-Erkenek-Deveyatağ 1 , N: 37.92338, E: 37.94709, 1300m, 27.V.1990, leg. B. Çıplak; 4ठึ, 7 우, Malatya-Pütürge-Esencik Village, N: 38.09296, E: 39.00990, 1600 m, 2.VI.1989, Leg. B. Çıplak; 1ð, 3 + + , Malatya-Beydağ1-Rafa, N: 38.329632, E: 38.324065, 2000m, 23.VII.1990, leg. B. Çıplak; $1 \delta$, 1 , MalatyaPütürge, Kubbe Mt., N:38.247580, E:38.705044, 1600m, 20.VI.1990, leg. B. Çıplak (all in AUZM).

Description. The description by Bolivar is functional. Also see Figs. 1, 2; A in Figs. 3, 4; B in Figs. 5-14.

Poecilimon isozonatus sp. $\mathrm{n}$.

http://zoobank.org/urn:lsid:zoobank.org:act:FD646C 32-75BB-4BD4-BC00-BE27211321B7, Figs. 1, 2; B in Figs. 3, 4; C in Figs. 5-14.

Material examined. Holotype, male: TURKEY: Konya-Taşkent-Afşar, N:36.90000, E:32.50000, 1682m, 16.VI.2014, leg. S. Kaya and D. Chobanov; Paratypes, $20 \hat{\jmath} \widehat{o}$ (2 nymph), 12 우 (2 nymph), same data as holotype; $5 \hat{\jmath} \widehat{\partial}, 10$ 우 (3 nymph); Niğde-Çamardı Vill., road fromYahyalı to Demirkazık Mt., N:37.83333, E:35.01667, 1539m, 17.VI.2014, leg. S. Kaya and D. Chobanov; 5ठิ๋, 2qo, Konya-Hadim, road to Gündoğmuş, N:36.88333, E:32.11667, 1887m,

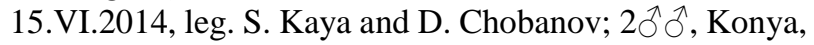
road between Bozkır-Hadim, 16.VI.2014, leg. S. Kaya

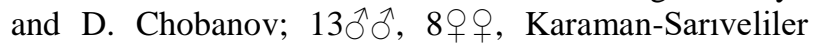
Village, 1610m 16.VI.2014, leg. S. Kaya and P.D. Chobanov (all in AUZM).

Diagnosis. $P$. zonatus and P. isozonatus sp. n. are very similar in traditionally used structures and metric characters (see Table 3), but genetic data clearly suggest each as a separate species (Table 1 and Fig. 2). The phenotypical characters distinguishing both are based on from male calling songs. Although these two species are morphologically similar, there is minor differences between both taxa such as the male cerci more slender, and more tapered distalward along incurved part in $P$. isozonatus sp. $\mathrm{n}$. The coloration of abdominal terga is distinct and mostly population specific and may differ in young and elder individuals, but do not correlate with species. Apart from these differences, a single description can be done for both species.

Description (holotype, male). Fastigium of vertex slightly narrower than scapus. Pronotum short, slightly constricted in the middle, median sulcus located after the middle, cylindrical in prozona and weakly raised in metazona, caudal margin of the disc slightly concave, medial carina occurs as a white line or totally absent, disk bordered by large light lines constituting roughly as ")(“" shape; paranotal margin almost straight along prozona and oblique along metazona. Tegmina short, extends beyond the posterior margin of pronotum, stridulatory vein covered by pronotum; stridulatory file with 43-53 teeth. Cerci cylindrical, roundly incurved as a bow; curvature is more prominent apicalward, with a robust but slightly tapered apex and 3-5 small denticles on its external margin and a more prominent one at the tip internally. Subgenital plate slightly longer than wide and oval in its distal half, distal margin is slightly concave.

Female. Similar to male in general. Pronotum just slightly raised in metazona, tegmina slightly extended beyond hind margin of pronotum. Subgenital plate triangular, ovipositor typical of the group.

Coloration. General coloration black with a light pattern; vertex black or with black spots on a greenish brown background, antennae black with regular white rings. Disc of pronotum with black dots or spots on a greenish brown background at the beginning of prozona, black in the middle and reddish brown in metazona; paranota with black spots on a greenish brown background; tegmina with typical black/light (marble or brown) pattern; all legs are black dorsally. Abdominal terga black in front $2 / 3$ and light in the remaining part, the black and light bands extend into each other showing a population-specific pattern.

Etymology. Although genetic and song data suggest discrimination of the new species, it is morphologically very similar to $P$. zonatus. The name isozonatus expresses this similarity.

Poecilimon ciplaki sp. n.

http://zoobank.org/urn:lsid:zoobank.org:act:6F15725 7-B942-4981-A806-B0BBFDC47C72, Figs. 1, 2; C in Figs. 3, 4; D and E in Figs. 5-14.

Diagnosis. All four species delimitation tests suggested $P$. ciplaki sp. n. as a distinct species, sister to $P$. zonatus $+P$. isozonatus $\mathrm{sp}$. $\mathrm{n}$. It can be easily diagnosed from other three species by the species-specific cerci (almost "L" shaped in P. ciplaki sp. n. while roundly curved in others with a more robust apex) and male calling 
song with longer syllable duration $[48 \mathrm{~ms}(42-72 \mathrm{~ms})$ in $P$. ciplaki sp. n., while $<25 \mathrm{~ms}$ in $P$. zonatus and $P$. isozonatus sp. n.]. Additionally, $P$. ciplaki sp. n. can be distinguished by a more slender general appearance.

Three of four automatic species delimitation tests suggest with high supporting values that the Denizli population is different from Antalya and Muğla populations. We therefore split the species into two subspecies and established $P$. ciplaki ciplaki subsp. n. and $P$. ciplaki denizliensis subsp. $\mathrm{n}$. The male cerci with a short inward curved part, more robust apex and extending beyond tip of subgenital plate distinguish $P$. ciplaki denizliensis subsp. n. from $P$. ciplaki ciplaki subsp. n. Below given description is valid for both subspecies.

Description (holotype, male). Fastigium of vertex narrower than scapus. Pronotum short, slightly constricted in the middle and widened front and backward, typical sulcus located in the middle or slightly behind middle; in profile pronotal disc concave being more raised in metazona, caudal margin of the disc slightly concave, medial carina absent, disc by irregular light lines; paranotal margin almost straight along prozona and oblique along metazona. Tegmina short, hardly extends to end of first abdominal tergum, its proximal one-third covered by pronotum, cubital vein covered by pronotum; stridulatory file with 43-53 teeth. Cerci cylindrical, incurved almost with a right angle, with a robust but slightly tapered apex and 5-8 small denticles along the tip most of which on external margin. Subgenital plate slightly longer than wide and oval in its distal half, distal margin slightly concave.

Female. Similar to male in general. Pronotum less raised in metazona, tegmina slightly extended beyond the hind margin of pronotum. Subgenital plate triangular, ovipositor typical of the group.

Coloration. Typical of $P$. zonatus complex. General coloration black with a light pattern. The vertex of fastigium black or with black spots on a brown background, antennae black with regular white rings. Disc of pronotum with black spots on a greenish brown background at the beginning of prozona, black in the middle and reddish brown in metazona; paranota with black spots on a greenish brown background; tegmina with typical black/light (marble or brown) pattern; all legs are black dorsally. Abdominal terga black in the proximal $2 / 3$ and light in the remaining part, the black and light bands extend into each other with a population-specific pattern.

Etymology. The name of the new species is dedicated to Prof. Dr. Battal ÇIPLAK who made a great contribution to our knowledge on Orthoptera.

Poecilimon ciplaki ciplaki subsp. $\mathrm{n}$.

http://zoobank.org/urn:lsid:zoobank.org:act:6F15725 7-B942-4981-A806-B0BBFDC47C72, Figs. 1, 2; C in Figs. 3, 4; D Figs. 5-14.

Material examined. Holotype, male; TURKEY: Muğla-Fethiye, road to Dalaman, N:36.75000,
E:28.90000, 258m, 14.V.2011, leg. S. Kaya, Z. Boztepe, Ö. Pekter; paratypes: $6 \widehat{\jmath}, 7$ 우우, same data as holotype; 1今, 4우, Muğla-Fethiye-Tuzlabeli, $1650 \mathrm{~m}$,

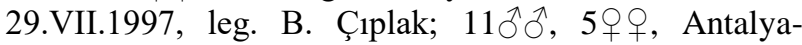
Elmal1-Bozöyük, Uzunkarış Hill, N:36.71667, E:30.11667, 1691m, 15.V.2011, leg. S. Kaya, Z. Boztepe,

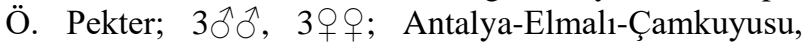
$\mathrm{N}: 36.59112$, E:30.00234, 1600m, 27.VI.1997, leg. B. Çıplak (all in AUZM).

Poecilimon ciplaki denizliensis subsp. $\mathrm{n}$. http://zoobank.org/urn:1sid:zoobank.org:act:6CB12F 26-DD4E-4947-AEEF-82E9C1B49391, Figs. 1, 2; E in Figs. 5-14.

Material examined. Holotype, male; TURKEY: Denizli, Honaz Mt., N:37.65027, E:29.25021, 1530m, 15.V.2011, leg. S. Kaya, Z. Boztepe, Ö. Pekter; Paratypes, $3 \circ 9$, same data as holotype (all in AUZM).

Etymology. The type locality of the new subspecies is in Denizli Province and the name of the new subspecies is based on Denizli province.

\section{Poecilimon tauricola Ramme, 1951 \\ Poecilimon tauricola Ramme, 195:331}

Type information. Holotype male; Turkey, Niğde, Ulukışla (Museum für Naturkunde, Berlin).

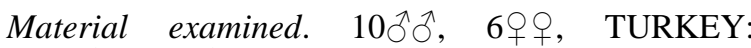
Erzurum-İspir, İkizdere, Ovit Mt., N:40.55097, E:40.91595, 1928m, 29.VII.2008, leg. S. Kaya, E. M. Korkmaz, M.S. Taylan (AUZM).

Description. See Ramme (1951) and also Figs. 1, 2; A in Figs. 5-14.

Remarks. The type locality of this species is located in the southern part of the Anatolian Diagonal (see Çıplak et al. 1993). The locality reported here is inside the Black Sea region, but still in association with the Diagonal. Comparison of the material genetically may provide interesting and more illuminative results. However, such a distribution pattern is not unexpected as there are further taxa ranging along the Diagonal (see Kaya \& Çıplak 2017).

\section{Discussion}

The present taxonomic study is based on three kinds of data; DNA sequences, male calling songs and traditionally used qualitative morphology. In our case, the power of mtDNA sequences to document biodiversity of a lineage seems to be the highest. Automatic species delimitation tests based on bioinformatic applications suggested a cryptic diversity within $P$. zonatus, and two new species and a new subspecies (Fig. 2). The high value of statistical support to each of the new species and absence of shared haplotypes provide significant support to this suggestion. Song characteristics are regarded as supportive to genetic data in exploring the biodiversity as documented in other species within Orthoptera (Heller 1988, Ragge \& Reynolds 1998). The syllable duration and the impulse number per syllable in particular allowed us 
to diagnose the genetically distinct units (Table 2). However, song data of some populations is still unavailable and obtaining song from these populations may provide a better description of biodiversity of this group. Contrary to DNA sequence and bioacoustics data, morphology was not so productive and remained insufficient in biodiversity documentation (compare the images given in Figs. 5-14). Only some taxa in the $P$. zonatus complex can be distinguished by morphology and cerci seem to be the most valuable diagnostic structure (Fig. 11). We can propose two reasons for the low use of morphology for taxa discriminations. First, the rate of morphological evolution may be lower than the DNA and bioacoustic data. Second, if the morphological divergence between these taxa cannot be explored by traditional examination of morphology, then application of geometric morphometry may provide a better resolution. It is worth noting that the linear metric morphology has not provided any diagnostic characters (see Table 3 ). In conclusion, the use of the combination of characters from different sources allowed a better documentation of biodiversity, and helped to discover two new species and one new subspecies. Thus, we consider $P$. zonatus, $P$. isozonatus sp. n., and $P$. ciplaki sp. n. as a complex within $P$. zonatus species group which also includes $P$. tauricola, $P$. variicercis and $P$. varicornis. Among the latter three species, the features of $P$. varicornis from Lebanon seem to fit the $P$. zonatus complex, while $P$. tauricola and $P$. variicercis are more divergent [as much as inferred from the original description and the data presented in Orthoptera Species File2 (Cigliano et al. 2018)].
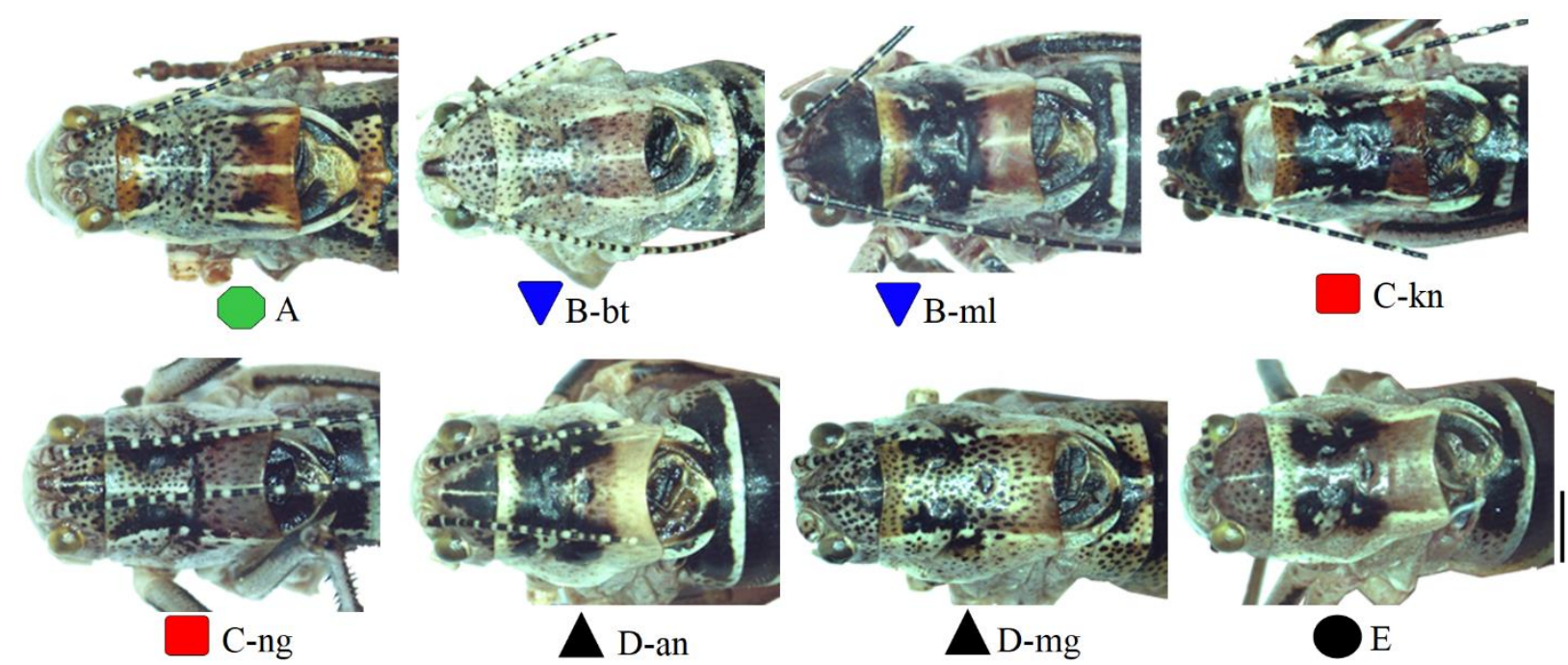

Fig. 5. Male pronotum from above (scale: $2 \mathrm{~mm}$ ): A- P. tauricola, B- P. zonatus (bt- Bitlis, ml- Malatya), C- P. isozonatus sp. n. (knKonya, ng- Niğde), D- P. ciplaki ciplaki subsp. n. (an- Antalya, mg- Muğla), E- P. ciplaki denizliensis subsp. n.
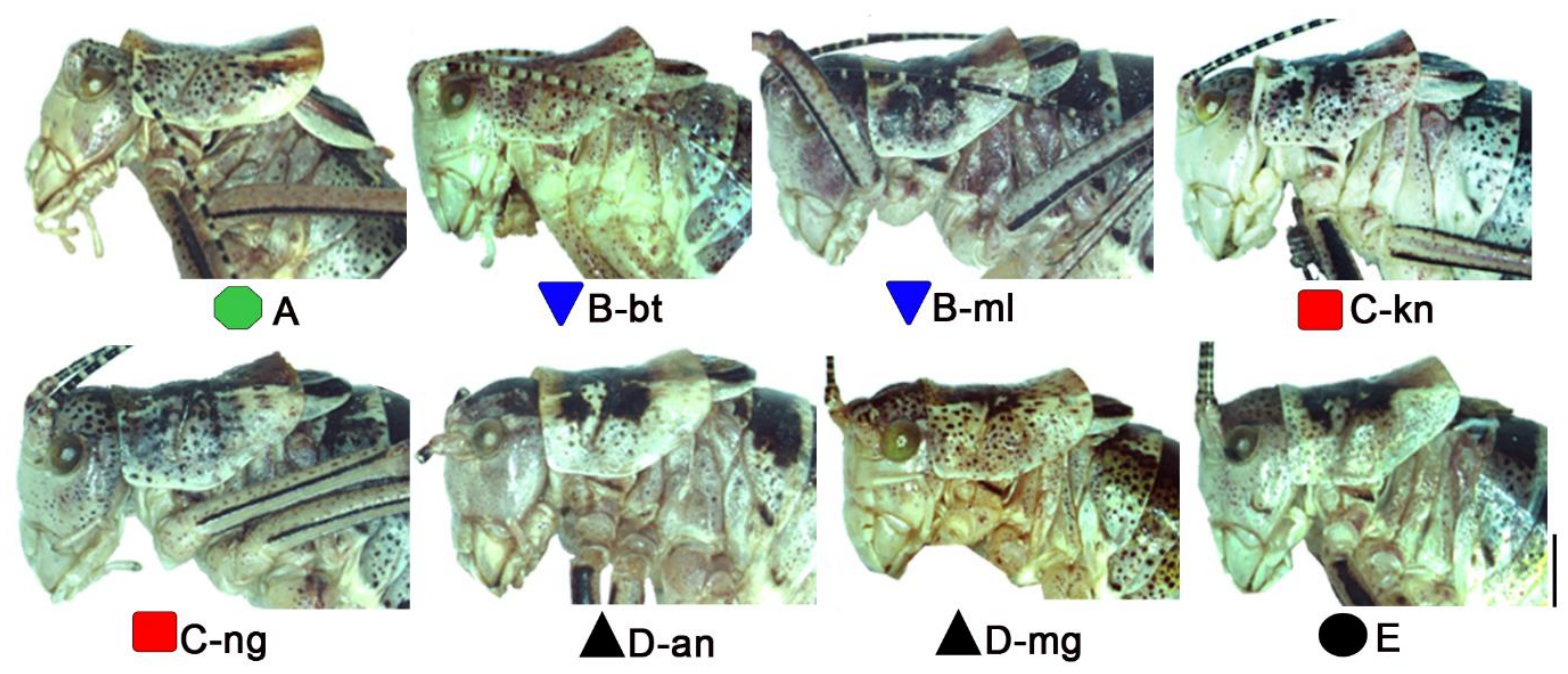

Fig. 6. Male pronotum in profile (scale: $2 \mathrm{~mm}$ ): A- P. tauricola, B- P. zonatus (bt-Bitlis, ml-Malatya), C- P. isozonatus sp. n (knKonya, ng- Niğde), D- P. ciplaki ciplaki subsp. n. (an-Antalya, mg-Muğla), E- P. ciplaki denizliensis subsp. n. 

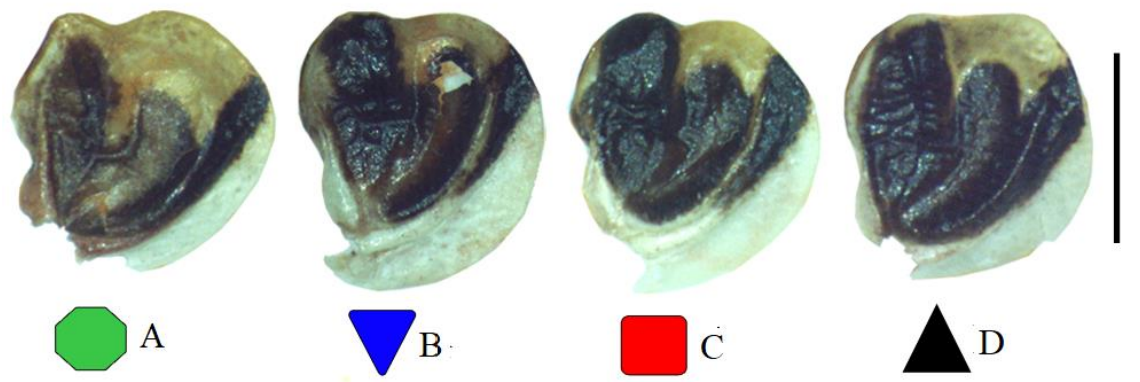

Fig. 7. Male tegmina (scale: $2 \mathrm{~mm}$ ): A- P. tauricola, B- P. zonatus, C- P. isozonatus sp. n., D- P. ciplaki ciplaki subsp. n.
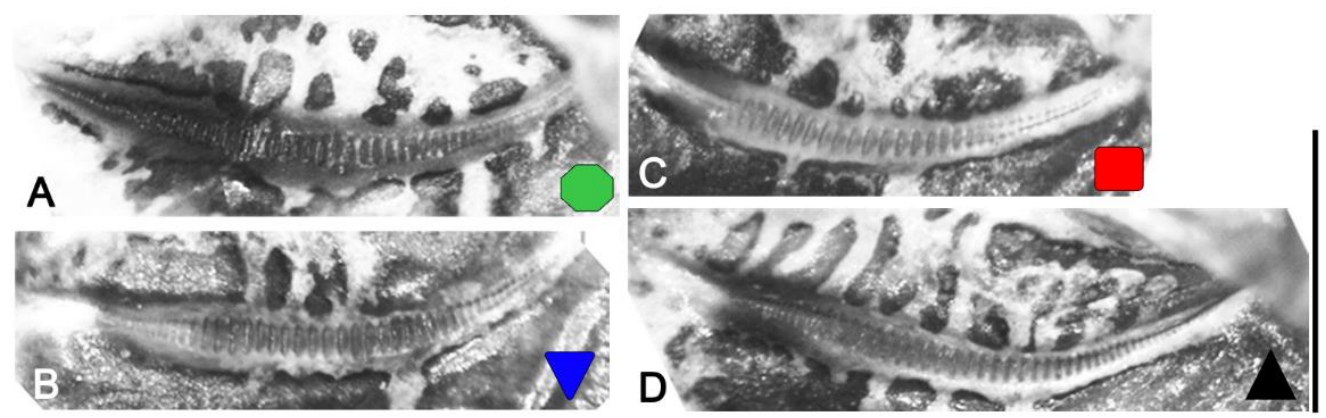

Fig. 8. Stridulatory file (scale: $1 \mathrm{~mm}$ ): A- P. tauricola, B- P. zonatus, C- P. isozonatus sp. n., D- P. ciplaki ciplaki subsp. n.
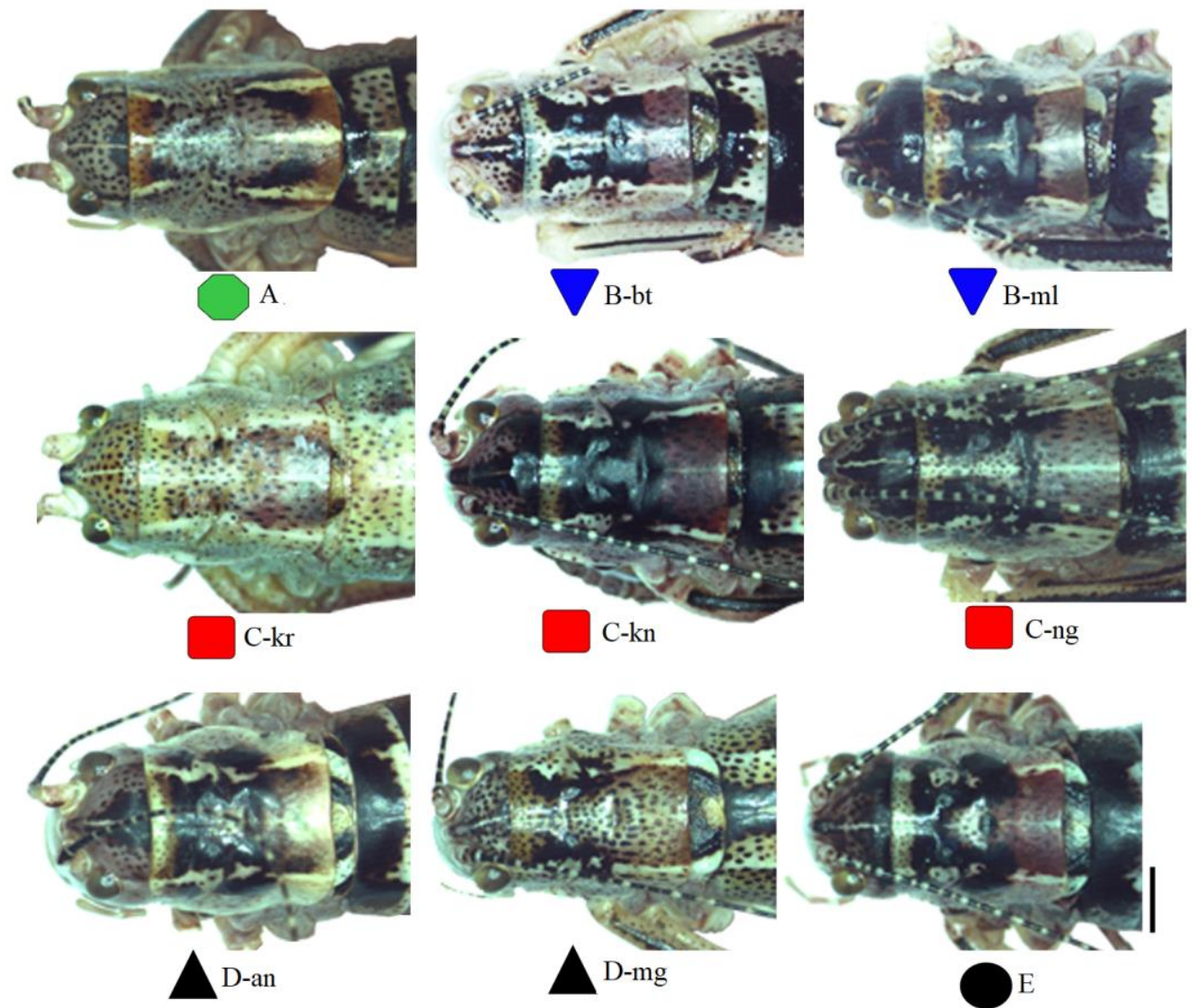

Fig. 9. Female pronotum from above (scale: $2 \mathrm{~mm}$ ): A- P. tauricola, B- P. zonatus (bt-Bitlis, ml-Malatya), C- P. isozonatus sp. n. (krKaraman, kn-Konya, ng- Niğde,), D- P. ciplaki ciplaki subsp. n. (an- Antalya, mg- Muğla), E- P. ciplaki denizliensis subsp. n. 

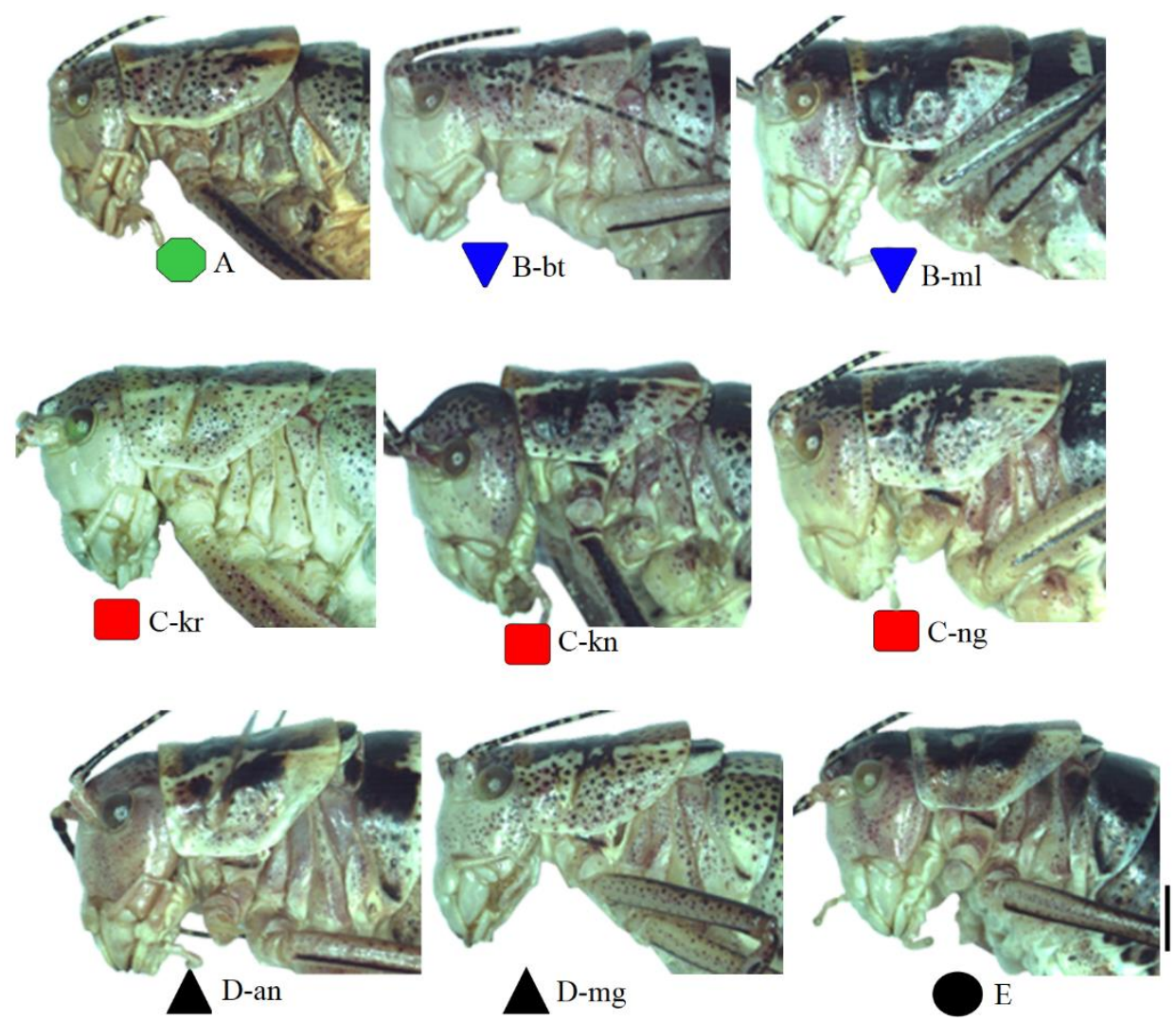

Fig. 10. Female pronotum in profile (scale: $2 \mathrm{~mm}$ ): A- P. tauricola, B- P. zonatus sp. n. (bt-Bitlis, ml-Malatya), C- P. isozonatus (krKaraman, kn- Konya, ng- Niğde,), D- P. ciplaki ciplaki subsp. n. (an-Antalya, mg- Muğla), E- P. ciplaki denizliensis subsp. n.

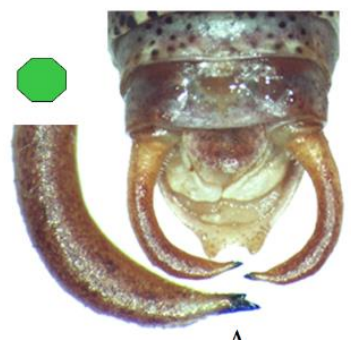

A
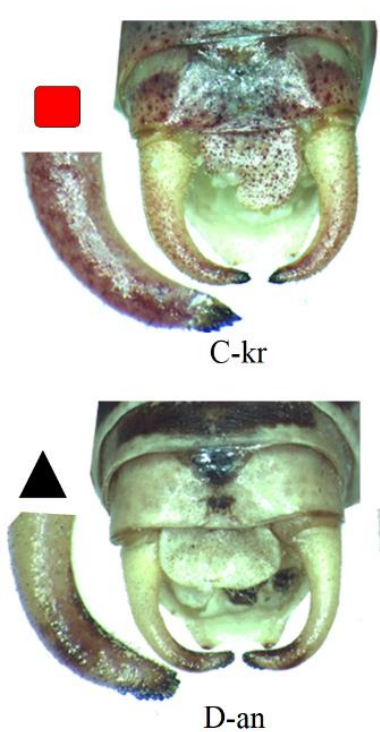

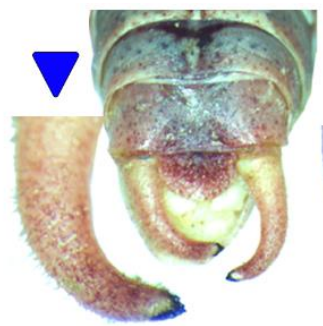

B-bt

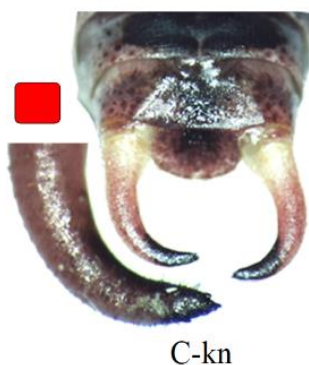

C-kn

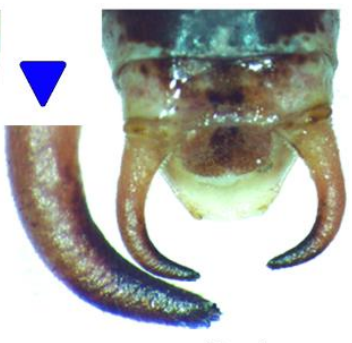

B-ml
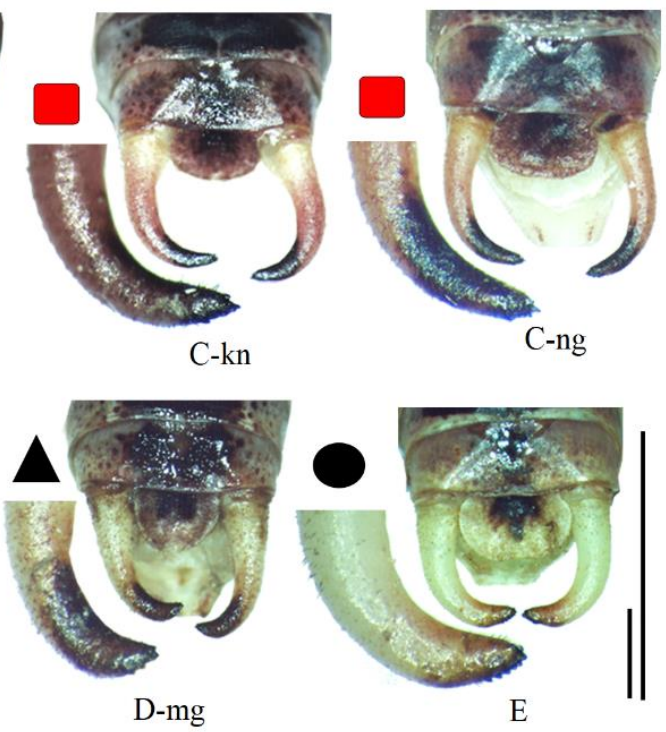

Fig. 11. Male cerci (scale: $2 \mathrm{~mm}$ ): A- P. tauricola, B- P. zonatus sp. n. (bt- Bitlis, ml- Malatya), C- P. isozonatus (kr- Karaman, knKonya, ng- Niğde,), D- P. ciplaki ciplaki subsp. n. (an- Antalya, mg- Muğla), E- P. ciplaki denizliensis subsp. n. 

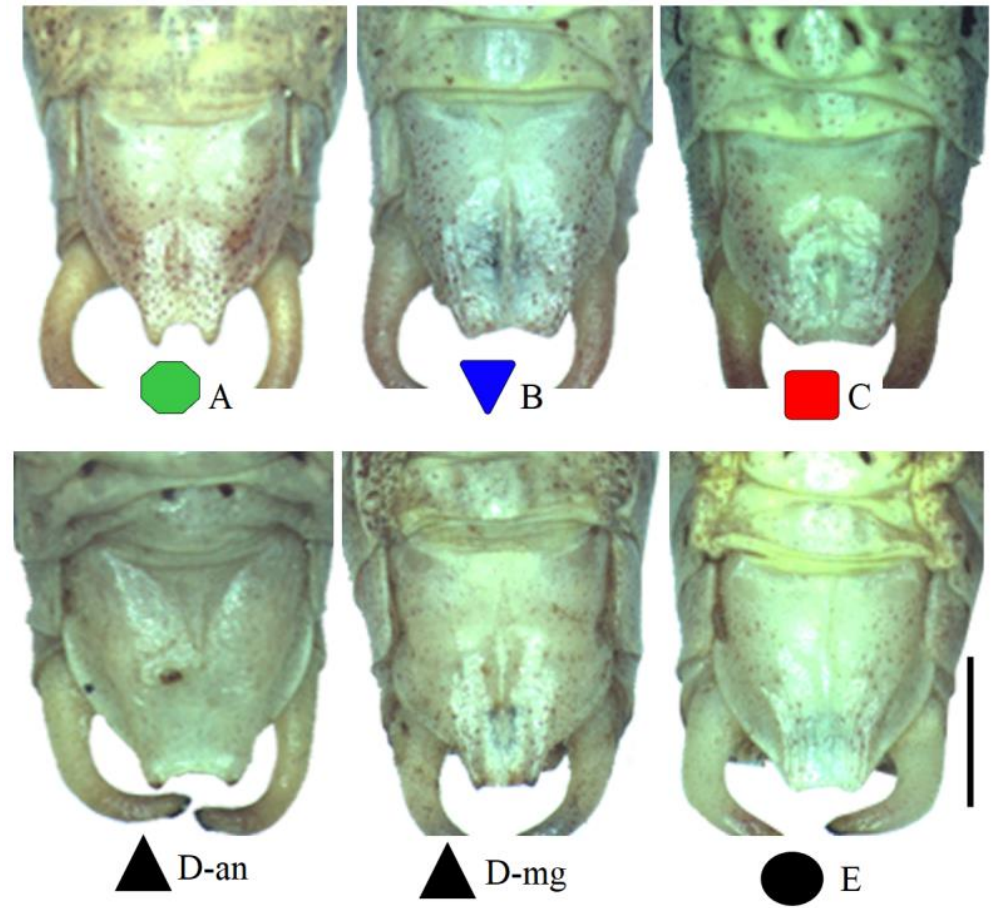

Fig. 12. Male subgenital plate (scale: $2 \mathrm{~mm}$ ): A- P. tauricola, B- P. zonatus, C- P. isozonatus sp. n., D- P. ciplaki ciplaki subsp. n. (anAntalya, mg- Muğla), E- P. ciplaki denizliensis subsp. n.
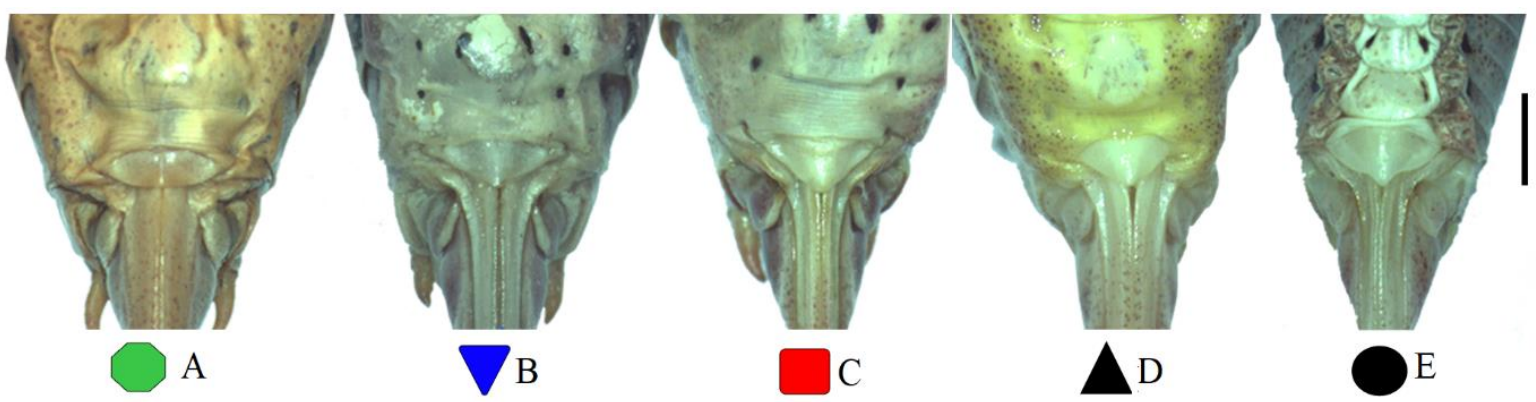

Fig. 13. Female subgenital plate (scale: $2 \mathrm{~mm}$ ): A- P. tauricola, B- P. zonatus, C- P. isozonatus sp. n., D- P. ciplaki ciplaki subsp. n., E- $P$. ciplaki denizliensis subsp. $\mathrm{n}$.

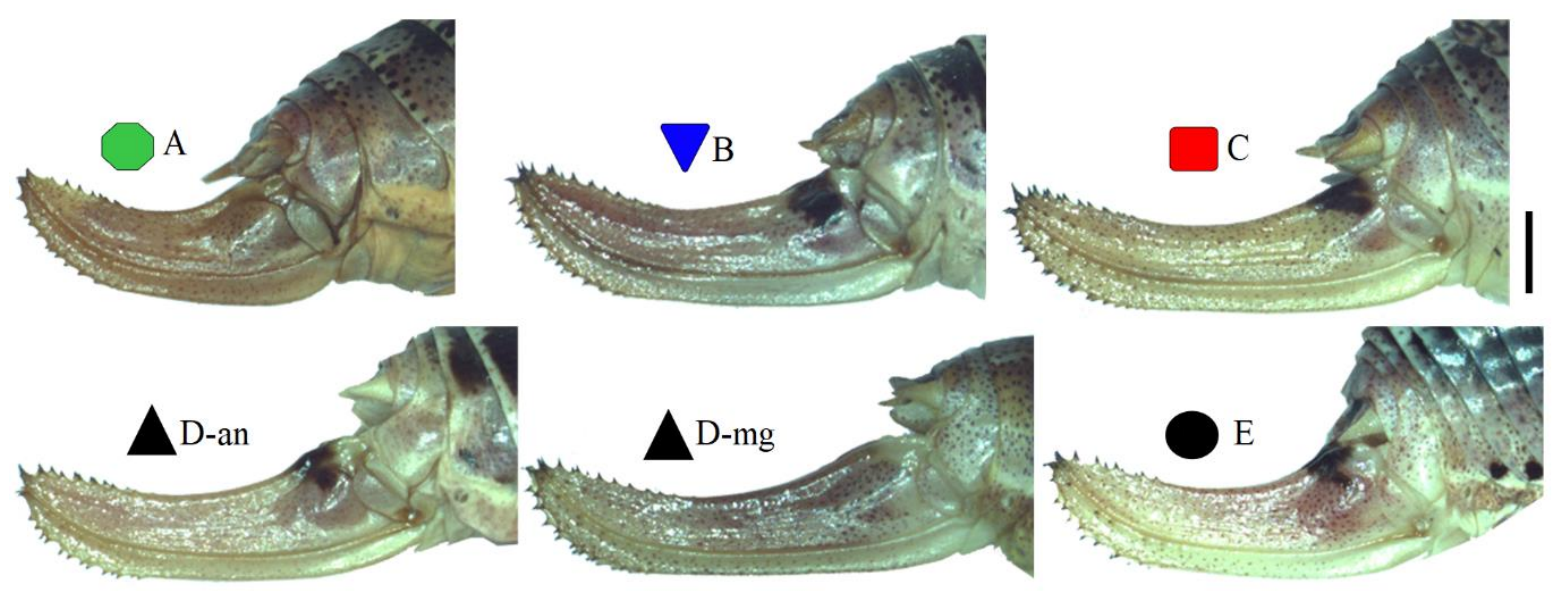

Fig. 14. Female ovipositor (scale: $2 \mathrm{~mm}$ ): A- P. tauricola, B- P. zonatus, C- P. isozonatus sp. n., D- P. ciplaki ciplaki subsp. n. (anAntalya, mg- Muğla), E- P.ciplaki denizliensis subsp. n. 
The second main implication of the present data is related to the specialty of Anatolian biodiversity, especially the one associated with mountain belts. Most of the populations reported here are restricted to highlands (Fig. 1). The range of $P$. tauricola correlates with the Anatolian Diagonal and that of $P$. zonatus with the East Anatolian highlands. $P$. isozonatus sp. n. ranged along the eastern part of Anatolia and P. ciplaki sp. n. in the western part of Mediterranean Taurus. More strikingly the total range of these species well fit the "Taurus Way" - an altitudinal entity providing a faunal connection between northeast and southwest Turkey (Çıplak 2008) and even between the Caucasus and the Balkans through southern Anatolia (Kaya \& Çıplak 2017). Thus, P. zonatus complex may constitute a model group to test the Taurus Way assumption by applying detailed phylogeographic analyses.

In conclusion, as suggested by present data and reported by other studies (see Çıplak 2003), Anatolian Mountains are the main areas harbouring Anatolian

\section{References}

1. Bey-Bienko, G.Y. 1954. Orthoptera. Leaf bush-crickets (Phaneropterinae). Fauna of the USSR, Vol. II, Sect. 2. Zoological Institute of the Academy of Sciences of the USSR, New Series, 59, 385 pp. (in Russian)

2. Cigliano, M.M., Braun, H., Eades, D.C. \& Otte, D. 2018. Orthoptera Species File. Version 5.0/5.0. http://Orthoptera.SpeciesFile.org (Date accessed: March 2018).

3. Chobanov, D.P., Kaya, S., Grzywacz, B., WarchałowskaŚliwa, E. \& Çıplak, B. 2017. The Anatolio-Balkan phylogeographic fault: a snapshot from the genus Isophya (Orthoptera, Tettigoniidae). Zoologica Scripta, 46(2): 165179 (doi:10.1111/zsc.12194).

4. Çıplak, B. 2003. Distribution of Tettigoniinae (Orthoptera, Tettigoniidae) bush-crickets in Turkey: the importance of the Anatolian Taurus Mountains in biodiversity and implications for conservation. Biodiversity and Conservation, 12: 47-64.

5. Çıplak, B. 2004. Biogeography of Anatolia: the marker group Orthoptera. Memorie della Società Entomologica Italiana, 82: 357-372.

6. Çıplak, B. 2008. The analogy between glacial cycles and global warming for the glacial relicts in a refugium: a biogeographic perspective for conservation of Anatolian Orthoptera, pp. 135-163, in: Fattorini, S. (ed) Insect Ecology and Conservation. Research Signpost, Kerela, India.

7. Çıplak, B., Demirsoy, A. \& Bozcuk, A.N. 1993. Distribution of Orthoptera in relation to the Anatolian Diagonal in Turkey. Articuluta, 8: 1-20.

8. Çıplak, B., Demirsoy, A. \& Bozcuk, A.N. 1996. Malatya Ensifera (Orthoptera, Insecta) faunas1. Turkish Journal of Zoology, 20: 247-254.

9. Darriba, D., Taboada, G.L., Doallo, R. \& Posada, D. 2012. jModelTest 2: more models, new heuristics and parallel computing. Nature Methods, 9: 772. biodiversity. As documented for P. zonatus complex, the specialty of the mountainous diversity is the existence of endemic forms. Thus, mountainous diversity requires special attention for conservation.

\section{Acknowledgement}

I am grateful to Prof. Dr. Battal ÇIPLAK for advising to study the $P$. zonatus group and allowing me to use facilities of his laboratory/collection in the Department of Biology, Akdeniz University, Antalya. Dr. Dragan CHOBANOV (Sofia), Dr. Mahir KORKMAZ, Dr. Mahir BUDAK (Sivas), Zehra BOZTEPE (Antalya) and Özkan PEKTER (Antalya) contributed to field studies. Dr. Bekir KABASAKAL (Antalya), Uğur KARŞI, Özgül YAHYAOĞLU and Onur ULUAR (Antalya) helped in laboratory studies and data preparations. My special thanks go to all. Although the group was not a subject of a specific project, this study would not be possible without projects of Prof. Dr. Battal ÇIPLAK granted by The Scientific and Technological Research Council of Turkey (TÜBİTAK).

10. Harz, K. 1969. Die Orthopteren Europas 1. Series Entomologica 5, The Hague (Dr. W. Junk N.V.), 749 pp.

11. Heller, K.-G. 1988. Bioakustik der europäischen Laubheuschrecken. Verlag Josef Margraf, Weikersheim, $358 \mathrm{pp}$.

12. Kaya, S., Çıplak, B., Chobanov, D. \& Heller, K-G. 2012. Poecilimon bosphoricus group (Orthoptera, Phaneropterinae): iteration of morpho-taxonomy by song characteristics. Zootaxa, 3225, 1-71.

13. Kaya, S. \& Çıplak, B. 2017. Phylogeography and taxonomy of the Psorodonotus caucasicus (Orthoptera, Tettigoniidae) group:independent double invasion of the Balkans from the Caucasus. Systematic Entomology, 42: 118-133.

14. Kaya, S., Boztepe, Z. \& Çıplak, B. 2015. Phylogeography of the Poecilimon luschani species group (Orthoptera, Tettigoniidae): a radiation strictly correlated with climatic transitions in the Pleistocene. Zoological Journal of the Linnean Society, 173(1): 1-21.

15. La Greca M. 1999. Il contributo degli Ortotteri (Insecta) alla conoscenza della biogeografia dell'Anatolia: la componente gondwaniana. Biogeographia, 20: 179-200.

16. Librado, P. \& Rozas, J. 2009. DnaSP v5: A software for comprehensive analysis of DNA polymorphism data. Bioinformatics, 25: 1451-1452.

17. Miram, E.F. 1938. New species of the genera Poecilimon Fisch. Fr. and Isophya Br. W (Subf. Phaneropterinae Fam. Tettigonoidea - long-horned grasshoppers) of the fauna of the USSR. Zoologicheskii zhurnal, 17: 348-372.

18. R Development Core Team 2018. R: A language and environment for statistical computing, Version 3.3.4. Available at http://www.R-project.org

19. Ragge, D.R. \& Reynolds, W.J. 1998. The Songs of the Grasshoppers and Crickets of Western Europe. Harley Books, London, 612 pp. 
20. Ramme, W. 1933. Revision der Phaneropterinen-Gattung Poecilimon Fisch. (Orth. Tettigon). Mitteilungen aus dem Zoologischen Museum in Berlin, 19: 497-575.

21. Ramme, W. 1951. Zur Systematik, Faunistik und Biologie der Orthopteren von Südost-Europa und Vorderasien. Mitteilungen aus dem Zoologischen Museum in Berlin, 27: 1-421.

22. Silvestro, D. \& Michalak, I. 2012. raxmlGUI: a graphical front-end for RAxML. Organisms Diversity \& Evolution 12: 335-337.

23. Simon, C., Buckley, T.R., Frati, F., Stewart, J.B. \& Beckenbach, A.T. 2006. Incorporating Molecular Evolution into Phylogenetic Analysis, and a New Compilation of Conserved Polymerase Chain Reaction Primers for Animal Mitochondrial DNA. Annual Review of Ecology, Evolution and Systematics, 37: 545-579.
24. Sevgili, H., Demirsoy, A. \& Durmuş, Y. 2012. Orthoptera fauna of Kemaliye (Erzincan). Hacettepe Journal of Biology and Chemistry, 40(4): 317-335.

25. Sueur J., Aubin T. \& Simonis C. 2008. Seewave: a free modular tool for sound analysis and synthesis. Bioacoustics, 18: 213-226.

26. Ullrich, B., Reinhold, K., Niehuis, O. \& Misof, B. 2010. Secondary structure and phylogenetic analysis of the internal transcribed spacers 1 and 2 of bush crickets (Orthoptera: Tettigoniidae: Barbitistini). Journal of Zoological Systematics and Evolutionary Research, 48: 219-228.

27. Ünal, M. 2010. Phaneropterinae (Orthoptera: Tettigoniidae) from Turkey and the Middle East II. Transactions of the American Entomological Society, 136: 125-183. 
